\title{
More on pejorative language: Insults that go beyond their extension
}

Elena Castroviejo, Katherine Fraser and Agustín Vicente ${ }^{1}$

Ikerbasque \& Universidad del País Vasco - Euskal Herriko Unibertsitatea (UPV/EHU)

\section{Abstract}

Slurs have become a big topic of discussion both in philosophy and in linguistics. Slurs are usually characterised as pejorative terms, co-extensional with other, neutral, terms referring to ethnic or social groups. However, slurs are not the only ethnic/social words with pejorative senses. Our aim in this paper is to introduce a different kind of pejoratives, which we will call "ethnic/social terms used as insults" (ESTIs), as exemplified in (European) Spanish, though present in many other languages and mostly absent in English. These are ethnic terms like gitano, lit. 'gipsy', which can have an extensional and neutral use, but also a pejorative meaning building on a negative stereotypical representation of the Romani community.

\section{Introduction}

Slurs have become a big topic of discussion both in philosophy and in linguistics. Linguistically, many authors analyse slurs as mixed expressives (McCready 2010; Gutzmann 2015). Roughly, they have both a truth-conditional meaning (also called "atissue") and a use-conditional (or "not at-issue") meaning. For instance, let Kraut stand for a slur word directed at German people: its analysis would be as in (1) (from Gutzmann and McCready 2016, ex. (3)):

(1) Dan is a Kraut.

a. Truth-conditional: 'Dan is German.'

b. Use-conditional: 'I have a negative attitude towards Germans.'

There is some debate as to whether this attitudinal approach towards slurs is appropriate (see, e.g., Camp, 2013, 2016, Hom, 2008, Jeshion, 2013, Marques \& García-Carpintero, forth, Williamson, 2009), as well as to how to model their alleged not at-issue (henceforth $\mathrm{NAI}$ ) content. Slurs are usually characterised as pejorative terms, co-extensional with other, neutral, terms referring to ethnic or social groups: Kraut is a slur, whereas German is the neutral term; Kraut has a NAI, projective and derogatory content that German lacks. One way of capturing such content is an attitudinal report as in (1)b: 'I despise this community / these people are not worthy of my esteem' (but see Marques \& GarcíaCarpintero, forth). Usually, however, NAI content is assumed to also include reference to some negative stereotype: 'I despise this community whose members are such and

\footnotetext{
${ }^{1}$ The order of authors is alphabetical.
} 
so and do this and that' (Camp, 2013; see below for discussion). Usually, the use of a slur extends this kind of signalling to the addressee. Thus, the speaker assumes that the attitude reported in the NAI content is also shared by the hearer and a group to which the speaker certainly belongs_-and seems proud of belonging in.

However, slurs are not the only ethnic/social words with pejorative senses. Here, we will focus on what we call "ethnic/social terms used as insults" (ESTIs), as exemplified in (European) Spanish. These are ethnic terms like gitano 'Romani' and moro 'Moor', terms for professions with behavioural stereotypes, such as camionero 'truck-driver' and portera 'doorwoman', and even terms for age groups, such as viejo/vieja 'old man/woman' and adolescente 'teenager' (see below). Many other languages (see §2 below for examples) have similar terms, but they have not been discussed in the literature.

To bring the point home, a term akin to an ESTI in English could be the term Nazi, which can be interpreted as a neutral term or as an insult, as exemplified in (2)a and b.

(2) Hubert is a Nazi.

a. Hubert belongs to the Nazi movement.

b. Hubert exhibits properties that belong to the social stereotype of a Nazi.

Crucially, under the interpretation in $(2) \mathrm{b}$, the noun is generally not predicated of the members of the neutral extension. ${ }^{2}$ Something analogous happens when speakers, addressing a boy, say you are such a girl, or addressing a grown up, you are such a child, etc.

Now focusing on social and ethnic terms, what is special in Spanish is that these two interpretations can be teased apart on the basis of the properties of the linguistic context in which the social and ethnic terms appear. Take (3) as a first illustration. ${ }^{3}$

(3) a. Antonia es porter-a.

Antonia is doorperson-FEM

'Antonia (female name) is a doorwoman.'

b. Antonio es *(un-a) porter-a.

Antonio is a-FEM doorperson-FEM

\footnotetext{
${ }^{2}$ Consider, for instance, the following naturally-occurring examples:

(i) a. But that's why I'm not a mod [moderator], I'm such a nazi when it comes to keep a forum straight. :oops:

https://www.mechspecs.com/threads/ace-of-spades-every-mech.9238/

b. I cannot thank enough my nazi of a father who ONLY allowed us to have water with meals growing up. Now I love it and don't have an addiction to soda or juice.

https://thehealthypineapple.com/tag/pretzels/

Thanks to Manuel García-Carpintero for providing the example.

${ }^{3}$ List of abbreviations: 1 = first person, 2 = second person, $3=$ third person, EVAL = evaluative morpheme, $\mathrm{FEM}=$ feminine, $\mathrm{MASC}=$ masculine, $\mathrm{NEG}=$ negation, $\mathrm{PL}=$ plural, $\mathrm{SG}=$ singular .
} 
'Antonio (male name) is a doorwoman.'

A sentence such as (3)a states that Antonia works as a door woman. As will be presented in greater detail in $\$ 2.1$ below, profession-denoting nouns must occur as bare nominals in copular constructions when it is conveyed that the subject is in the extension of the noun. The presence of the indefinite would render the sentence unacceptable under this interpretation. Let us now turn to (3)b. First, observe that the noun is necessarily preceded by the indefinite. Second, portera is inflected as a feminine form and the subject is male, so we can rule out the possibility that the copular construction conveys that Antonio works as a doorman. In Spanish, evaluative nouns in copular constructions are introduced by the indefinite un (i.e., they do not appear bare), so the presence of the indefinite in (3)b is flagging that only an evaluative interpretation of the noun is available. In fact, in this case, the feminine word for this profession, portera 'doorwoman', must be interpreted as a pejorative evaluative noun, typically predicated over individuals who are not members of its extension, to suggest that they are gossips. This minimal pair evidences how the ethnic and social terms depicted in this paper are used as insults in specific linguistic contexts. Throughout the paper, we will make use of these linguistic constraints to explain the distribution of ESTIs in Spanish and to compare ESTIs with other slurring expressions, so as to prove that ESTIs are indeed a separate category on their own merit.

An important issue to be addressed before we begin with the presentation of linguistic data is the extent to which we can consider ESTIs to be pejorative terms. ${ }^{4}$ One could think that the pejorative uses of the terms we will discuss are the effect of coercion or of pragmatics, with the implication that ESTIs would not form a class of pejoratives. There would be pejorative uses of the terms that we deal with, but such uses would depend on, e.g., the availability of a stereotype to both speaker and hearer, and not on conventions or anything semantic.

We think that ESTIs are polysemous terms, such that the relationship between the extensional and the pejorative uses of an ESTI is akin to the mass/count uses of polysemous expressions such as beer (I drank beerl I drank a beer). In the "beer" case, the term has a certain meaning/sense in certain linguistic environments ("mass" environments), and another meaning/sense in other environments ("count" environments). However, this does not imply that, e.g., the indefinite article coerces a mass meaning into a count meaning. At least, some empirical evidence suggests the

\footnotetext{
${ }^{4}$ Thanks to an anonymous referee for raising this issue.
} 
contrary (Schumacher, 2013): retrieving the count meaning is not costly compared to other cases where there is coercion (e.g., the "ham sandwich" case). So, the fact that the different meanings typically appear in different syntactic environments does not mean that they are not polysemous (as the "beer" case attests).

Then, there is, as a matter of fact, a conventional stereotype that is retrieved by default in non-extensional uses of our paradigmatic example, gitano, something that does not happen in cases like alemán 'German', which can pick up different stereotypes on different occasions in constructions such as $X$ es muy alemán (' $X$ is very German'), where alemán may stand for stubborn, but also for efficient, etc. Aside from the linguistic facts that we will introduce below, which make the difference between alemán and gitano more perspicuous, this fact alone suggests that the relation between the ESTI gitano and the stereotype is conventional, i.e. that the stereotype is a conventional meaning of the term.

Also, the empirical evidence collected by authors working on dual-character concepts (Reuter, 2019) supports our view. According to these authors, some terms/concepts have a normative dimension (e.g., scientist): one way to test whether they have such normative dimension is to ask subjects to react to true modification (such as Jane is a true scientist). When the features listed by subjects show a high degree of coincidence, we have reason to believe that people share a certain ideal of what it is to be, e.g., a scientist. In such cases, concepts themselves are said to have a dual character (and not all concepts have such a dual character: co-worker does not have a normative dimension). We think that in the "gitano" case the issue is even clearer, to the extent that the pejorative meaning of the word appears in some dictionaries. ${ }^{5}$ So, again: (i) the stereotype the term relates to is stable across subjects and contexts, and (ii) using the term is a conventional way to refer to the features that form part of the stereotype (i.e., it is a conventional way to mean "robber, liar", etc.). The picture then is one where we have two conventional uses of a term, both being easy to retrieve (i.e. one does not have to activate one as a means to retrieve the other). This strongly suggests the polysemy

\footnotetext{
${ }^{5}$ The pre-2014 editions of the RAE (Royal Academy for the Spanish Language) dictionary used to capture this meaning in this way: "trapacero; que estafa u obra con engaño" ('crook; someone who scams or deceives'). Then, in 2014, after protests from the Romani community, it explained the content of the pejorative meaning of 'gitano' simply by making it a synomym of "trapacero" (crook) and adding, as metadata, that the meaning is pejorative. Representatives of the Romani community are still fighting against the pejorative meaning of gitano being listed at all.
} 
hypothesis is true (Vicente, 2018), and so the view that ESTIs form a particular class of pejorative terms.

Now, the paper is organised as follows: in the next, second, section we introduce ESTIs and present data that illustrate their behaviour, showing that they belong to a different category than slurs. While ESTIs pattern together with other evaluatives, slurs belong to a different class of pejoratives. In the third section we propose an analysis of their $\mathrm{Al}$ and NAl content, again comparing them to slurs; the discussion of slurs includes previous accounts that are relevant to exploring further the differences between ESTIs and slurs. We will not do a thorough revision of the different positions on the $\mathrm{Al}$ and NAI content of slurs, since our main purpose here is to convince the reader that the pejoratives that we talk about differ in many dimensions from slurs. In this regard, we argue for two key characteristics of ESTIs: the Al content is a stereotype and the NAI content a generic that collects stereotypical beliefs. We finally contend that using ESTIs is a particular way of being racist, classist or sexist, which endorses and perpetuates stereotypes.

\section{Data}

ESTIs are highly productive in (European) Spanish. However, this phenomenon is not limited to Spanish: these uses of ethnic terms, terms of professions or of ages as insults can be found in many other languages. For instance, German has Bauer ('farmer', with an inference of being simple-minded), Oma/Opa,('grandma'/'grandpa', with an inference of being grumpy, boring, conservative), Schwabe ('Swabian', a region in southwestern Germany; an inference is being tight-fisted or cheap); Italian has pescivendola ('woman who sells fish') and ortolana ('woman who sells vegetables'), both with an inference of being crude, loud, unrefined, and camionista ('truck driver'), as someone rude, rough, uneducated and dirty; $\mathrm{BCS}^{6}$ has seljak ('peasant', with an inference of being crude or unrefined), etc. The ESTI 'gipsy' is also found in a number of languages, with a pejorative meaning very close to that of Spanish: e.g., zingaro in Italian or tigan in Rumanian. Traditional terms like these that refer to the Romani people oscillate between being ESTIs, being slurs and being a more complicated thing that we will not deal with here: slurs towards members and insults directed at non-group members at the same time.

English is interestingly different from all these languages in that, while proliferous in slurs and similar pejoratives, it has few ESTIs. The now archaic use of the verb to jew (down), meaning 'to cheat', has obvious similarities with the pejorative use of gitano in Spanish,

\footnotetext{
${ }^{6}$ Bosnian/Croatian/Serbian.
} 
although it lacks the neutral use that gitano has. Uses of child and teenager for recklessor immature-behaving adults, grandpa/grandma or dad/mom for non-family members with conservative/boring inferences, or the sexist use of girl, prima facie are similar to ESTIs, although they lack a key component of them, which is the stability of the stereotype. ${ }^{7}$ As mentioned above, another good example is the use of Nazi to denote a cluster of properties associated with actual Nazism. The rest of this article will focus on the European Spanish examples, using gitano 'Romani' in particular. This section will provide linguistic diagnostics for ESTIs.

\subsection{ESTIs appear in the syntactic environments of evaluative nouns}

The main property of ESTIs is that they behave like evaluative nouns (also known as degree or quality nouns) from a purely linguistic point of view. That is, they are acceptable only in syntactic contexts that are available to nouns such as genio 'genius', idiota 'idiot' or chupatintas 'pencil-pusher, lit. ink-sucker'. This shows a striking contrast with slurs, which can occur (and typically occur) outside such contexts.

In her typology of evaluative nouns, Masià (2019) describes these nouns as not only assigning a property, but also expressing a value judgment, which can be positive, but tends to be negative. In that sense, they are analogous to "thick terms" in philosophy (Williams, 1985). In previous literature, authors like Milner (1978), Suñer Gratacós (1999), Hernanz (2001) and Ruwet (1982) assume evaluative nouns have an affective feature, whereas Bolinger (1972), Mathushanksy (2002) or Espinal (2013) believe they lexicalize a degree argument. Masià (2019) proposes that the key component all evaluative nouns share is that they are expressive in the sense of Potts (2005).

Our goal here is not to investigate evaluative nouns as such, so we will not commit to which option is best, but we will have something to say about ESTIs' NAI behaviour in section 3. In what follows, we will display the main properties of ESTIs as a kind of evaluative noun, pointing at differences with slurs.

\subsection{1. $N_{1}$ of an $N_{2}$ construction}

\footnotetext{
${ }^{7}$ As a referee points out, there is no fixed subset of negative or positive properties of a cluster associated with a term that would guarantee that these terms will be systematically used as a pejorative or an insult. Take 'dad' (examples provided by the reviewer):

He wears high-waisted trousers and has been putting on weight. He's such a dad! (he has a negative feature of dads)

She raised all the kids alone, working full time. She was a mom and a dad for them (i.e., she has the positive features of moms and dads)

He fathered 7 children, abandoned them, and never paid any childcare. He's not a (real/true) dad. (i.e., he lacks the positive features of dads).
} 
As shown by Bolinger (1972), Suñer Gratacós (1990,1999), Doetjes and Rooryck (2003), Villalba and Bartra-Kaufmann (2010), Masià (2019), evaluative nouns can occupy $N_{1}$ in the $N_{1}$ of an $N_{2}$ construction. This is exemplified in (4), where evaluative and nonevaluative nouns are compared. In (5), we see how an ESTI can occupy $N_{1}$, unlike slurs. ${ }^{8}$

(4) Masià (2019: 298-299)
a. la sociata / la matasanos de la vecina
the.FEM socialist.pejorative the.FEM witch_doctor of the.FEM neighbour.FEM
'that socialist.pejorative/the witch doctor of a neighbour'
b. \#la política / la médica de la vecina
the.FEM politician.FEM the.FEM doctor.FEM of the.FEM neighbour.FEM
\#'that politician/doctor of a neighbour'
(5) a. el gitano de tu cuñado
the.MASC Romani.MASC of your brother-in-law
'your Romani_ESTI of a brother-in-law'
b. \#el gabacho de tu cuñado
the.MASC French_slur.MASC of your brother-in-law
\#'your French_slur of a brother-in-law'

\subsubsection{Verbless exclamatives}

As studied by Vinet (1991), Hernanz (2001), Munaro (2006) and Masià (2019), evaluative nouns such as matasanos 'quack, witch doctor' and sociata 'socialist +pejorative' can occur as verbless exclamatives of the sort depicted in (6), to be compared with the illformedness of utterances with the (by default) non-evaluative nouns médica 'doctor.FEM' and política 'politician.FEM', (7).

(6) ¡Una matasanos / una sociata, esta vecina! (Masià 2019:300)

'A witch doctor / a socialist, this neighbour!'

(7) \#¡Una médica / una política, esta vecina!

\#'A doctor / a politician, this neighbour!'

Likewise, an ESTI can be the main predicate of a verbless exclamative, (8), in opposition to a slur, (9).

(8) ¡Un gitano, tu cuñado!

'A Romani_ESTI, your brother-in-law!'

(9)\#¡Un gabacho, tu cuñado!

\footnotetext{
${ }^{8}$ The English equivalent of the $N_{1}$ of an $N_{2}$ construction is best with a demonstrative or possessive pronoun modifying $N_{1}$, unlike the Spanish.
} 
\#'A French_slur, your brother-in-law!'

\subsection{The emphatic Spanish indefinite}

Copular constructions in Spanish obey different constraints from copular constructions in other languages, including English. Focusing on noun phrase predicates, ${ }^{9}$ two main options are available, either a bare noun (i.e., without a determiner) and a noun phrase headed by a determiner. Interestingly, depending on the properties of the predicate noun, different interpretations may arise. ${ }^{10}$ For instance, professions are introduced as bare nouns in Spanish, without the indefinite determiner (unlike English). That explains the fact illustrated in (10).

(10) Sara es ( $\left.{ }^{*} u n a\right)$ neurólog-a.

$$
\text { Sara is a neurologist.FEM }
$$

'Sara is a neurologist.'

In more depth, descriptive grammarians analyse the [Copula + bare noun] construction as bearing a classificatory interpretation. Hence, Fernández Leborans (1999) claims that the attribute (i.e., the bare noun) characterizes an individual as a member of a category. This generally applies to nouns that refer to humans and this predication concerns sociocultural distinctions, social roles or functions, such as profession, rank, post and profession. As for ethnic terms such as alemán 'German', traditional grammarians analyse them as relational adjectives that can be re-categorised as nouns (see e.g. Bosque 1993, 1999). Hence, it is expected that they appear bare in copular constructions to indicate that the subject is a member of the extension, although they can also behave like nouns in other linguistic contexts, as will be clear shortly. Going back to professions, if we want to say of a man that he works as a writer, in Spanish we have to use a bare noun, as in (11)a. As observed by Bosque (1996), this kind of predication is an answer to a question of the sort in (11)b. Finally, a last grammatical property of this construction has to do with the kind of modifiers the predicate noun can bear, namely relational adjectives and other modifiers that create subkinds. In (11)c, the prepositional phrase modifier creates a subkind of writer. In contrast, a restrictive modifier that narrows down the set in the extension of the noun is unacceptable in this position.

\footnotetext{
${ }^{9}$ And leaving aside specificational and equative copular constructions. On this, see Higgins (1979), Partee (1986), Heycock (1994), Moro (1997) and Mikkelsen (2005), a.m.o. The cases we deal with are predicational, whereby the predicate is the noun phrase following the copula and the subject is another noun phrase which is the argument of the predicate.

10 On the distinction in Italian, see Korzen (1982), in French, Jeunot (1983) and Pollock (1983), and in Danish, Mikkelsen (2005); see also Geist (2019) for a brief discussion of the German parallel.
} 
(11) Bosque (1996) $)^{11}$

a. Este hombre es escritor.

this.MASC man is writer

'This man is a writer.'

b. ¿Qué es este hombre? what is this.MASc man

'Who is this man?'

c. Este hombre es escritor \{de novela corta / *que conocí en la biblioteca\}. this.MASC man is writer of novella that I met in the library

'This man is a writer \{of novellas/*that I met in the library\}.'

Interesting for our purposes is the comparison between the previous structure and the [Copula + indefinite noun phrase] construction. Grammarians such as Bosque (1996) and Fernández Leborans (1999) describe this structure as carrying an identificational interpretation. It distinguishes the subject among the individuals in the relevant contextual domain. Usually, the noun occurs with an additional restrictive modifier. Otherwise, the result can be unnatural, since the noun on its own is not enough information to specify who the referent of the subject is. To grasp the difference with the [Copula + bare noun] construction, let us compare (11) with (12). (12)a is natural to the extent that predicating of the subject that he is a writer is enough to pick out who that man is (among the rest of relevant individuals). Unlike in (11)b, the sentence in (12)a is an answer to the question in (12)b. And, finally, while subkind-making modifiers are allowed, restrictive modifiers such as the one in (12)c are also possible in this construction.

(12) Bosque (1996)

a. Este hombre es un escritor. this.MASC man is a.MASC writer.MASC

'This man is a writer.'

b. ¿Quién es este hombre?

who is this.MAsc man

'Who is this man?'

c. Este hombre es un escritor \{de novela corta / que conocí en la biblioteca\}. this.MASC man is a.MASC writer of novella that I met in the library

'This man is a writer \{of novellas/that I met in the library\}.'

\footnotetext{
${ }^{11}$ We provide our own glosses and translations of examples from sources written in Spanish (Bosque, 1996; Farnández Leborans, 1999; and Fernández Lagunilla, 1983).
} 
Therefore, a social term (such as one referring to a profession) will be interpreted in different ways depending on whether it is introduced as a bare noun or as an indefinite noun phrase.

Now, in Spanish, the indefinite noun phrase can still receive a different interpretation as long as the noun that is introduced is evaluative (see $\$ 2.1$ for a list of syntactic constructions that are sensitive to this distinction). In fact, authors such as Fernández Lagunilla (1983), Portolés (1993, 1994), Bosque (1996), Leborans (1999), di Tullio and Suñer Gratacós (2008) and Gutiérrez-Rexach (2010) have called this context the 'emphatic un construction' and have treated this environment as another one of the syntactic structures that are sensitive to evaluativity. ${ }^{12}$ Gutiérrez-Rexach (2010: 684) characterizes this construction as "[...] a way of expressing evaluative predication, namely, when a predicate expresses a speaker's strong personal assessment of a group or class (of a depreciative or derogatory nature in most occasions)." In fact, it is usually negative, e.g. (13)a; but it can also be positive, e.g. (13)b.

(13) Fernández Leborans (1999: 2373)

a. Juan es un \{viejo / egoísta / impostor / ladrón / tirano ... \}.

Juan is a.MASC old_man selfish_person imposter thief tyrant

'Juan is an \{old man / a selfish person / an imposter / a thief / a tyrant ...\}.'

b. Pepe es un \{valiente / genio / sabi-o / afortunad-o ... \}.

Pepe is a.MASC brave genius wise-MASc lucky.MASC

'Pepe is \{brave man / genius / wise man / lucky man ... \}.'

Importantly, nouns that only have an evaluative reading must occur in the Spanish emphatic indefinite environment, as shown in (14).

(14) Bosque (1996)

a. Este hombre es *(un) monstruo.

this.MASC man is a.MASC monster

'This man is a monster.'

b. María es *(una) farsante.

María is a.FEM fraud

'María is a fraud.'

\footnotetext{
12 Emphatic un also occurs beyond copular constructions, in examples such as (i), from Rigau (1999: 324). In these contexts, the indefinite is unacceptable unless a modifier is added that allows for the evaluative interpretation of the noun.

(i) a. Tengo un miedo *(que me muero).

have.1SG a.MASc fear that me die.1SG

'I am (terribly) scared.'

b. Tiene unos hijos * (que son insoportables).

has.3SG a.MASC.PL that are.3PL unbearable.PL

'S/he has (unbearable) children.'
} 
On the other hand, nouns that only have a classificatory interpretation and do not provide enough information to identify the subject are unacceptable in this environment, as illustrated in (15).

(15) Fernández Lagunilla (1983)

a. Es un $\quad$ ppadr-azo / ??padre\}.

is a.MASC father-EVAL father

'He is $\{$ an indulgent father / a father $\}$.'

b. Es un \{tirano / ??gobernador\}.

is a.MASC tyrant governor

'S/he is \{a tyrant / governor\}.'

Interestingly, ethnic terms are typically associated with (different) stereotypes, and yet they are not evaluative and, as such, can occur bare with the copula but not with the indefinite determiner in the emphatic interpretation (they would then have a marginal identificational interpretation which could be improved with the addition of an adequate restrictive modifier). See for instance (16).

(16) Manuel es ( $\left.{ }^{*} u n\right)$ alemán.

Manuel is a.MASc German

'Manuel is (a) German.'

Summing up, where do the nouns that behave as ESTIs stand with respect to the emphatic un construction? On the one hand, they are terms which can be used to classify individuals under a social or ethnic category, so they are acceptable as bare predicates of the copula, (3)a and (17)a. On the other hand, they are evaluative in virtue of being associated with negative stereotypical properties, ${ }^{13}$ which legitimates their occurrence as predicates introduced by the indefinite article under the emphatic interpretation, (3)b and (17)b. Remember that the identificational interpretation is quite marginal because of

\footnotetext{
${ }^{13}$ We have studied the most usual -the conventional- case where the evaluative character of gitano is negative. However, it can also have a positive meaning. If a Romani mother tells her son (i), she may be reminding him to be proud of what he is-and to act accordingly. In such a case, she will be conveying the positive ideal that Romani people may have of themselves (which can be shared by other, non-Romani, speakers). It will be a reminder of the positive features that he has by virtue of being a Romani, for instance, being a free spirit loyal to the community.

(i) Recuerda: eres un gitan-o.

remember are.2SG a.MASC Romani-MASC

'Remember: you are a Romani.'

Gitano here is interpreted in a way similar to a family name. This is typically used with last names, as illustrated in (ii), where Lannister is a last name in the fictional Game of Thrones. Lannister is presumed to evoke positive properties that have been attached to the lineage since its beginning.

(ii) Recuerda siempre que eres un Lannister.

'Always remember you are a Lannister.'
} 
the lack of further specification that can help identify the referent of the subject among the rest of individuals in the relevant domain.

(17) a. El Chato es gitano. the Chato is Romani

'Chato is (a) Romani.'

b. Manuel es un gitano.

Manuel is a.MASC Romani

'Manuel is a Romani_ESTI.'

\subsection{Degree modification}

Like evaluative nouns such as idiota 'idiot', which have been argued to include a degree argument (see e.g. Masià, 2018), ESTIs can be said to be gradable. For instance, Masià's degree nouns can be modified by evaluative adjectives such as suprising or unbelievable to express that the property denoted by the noun is held to a high degree (de Vries 2010, Nouwen 2011, Masià 2019). The same holds for size adjectives such as big, as observed by Morzycki (2009). The contrast is shown in (18).

(18) Masià (2019:302)

a. María es una idiota \{increíble / enorme\}.

DEGREE

María is a.FEM idiot incredible enormous

'María is an \{incredible / enormous\} idiot.'

b. Es una \{matasanos / sociata\} \{increíble / enorme\}.NON-DEGREE is a.FEM qua ck socialist_pejorative incredible enormous

'S/he is an \{incredible / enormous\} \{quack / socialist_pejorative\}.'

If we run the same test with an ESTI, probably both interpretations are possible, but the degree reading is indeed available, (19).

(19) a. Tu cuñado es un gitano \{increíble / enorme\}.

(NON-)DEGREE your brother-in-law is a.MASc Romani incredible enormous 'Your brother-in-law is an \{incredible / enormous\} Romani_ESTI.'

b. Ramona es un-a porter-a \{increíble / enorme\}. (NON-)DEGREE Ramón is a-FEM doorperson-FEM incredible enormous 'Ramona is an \{incredible / enormous\} doorwoman_ESTI.'

The non-degree interpretation in (19)a is one where your brother in law has the negative properties of the stereotypes associated with the ESTI and is incredible / huge, the 
degree reading would be one where your brother in law has many negative stereotypical properties of the sort described in the present paper. Likewise for (19)b.

\subsection{The auténtico environment}

Masià (2017) argues that Spanish prenominal adjectives of veracity such as verdadero 'true' and auténtico 'authentic' must modify nouns that exhibit a kind of vagueness induced by having a structure akin to a prototypical structure. Hence, (20)a is interpreted as a function that applies to an individual $x$ and it is true iff in all relevant contexts, $x$ is an artist. Since artist is a vague noun in the said sense, in order to determine its extension, ideal values in dimensions associated to the noun are evoked (for similar data on true modification, see: Knobe et al., 2013, del Pinal \& Reuter, 2016). For instance, high values in criteria such as creativity, originality, output and personality. So, (20)a would be true if and only if the person said to be a true artist fits the ideal of an artist (very creative, original, etc.). Interestingly, in Spanish, certain preposed and postposed adjectives are interpreted differently. Adjectives of veracity are such a case. In contrast with (20)a, (20)b would be true of an individual who is a professional artist.

(20) a. un-a \{verdadera / auténtica\} artista

a-FEM true authentic artist

b. un-a artista \{verdadera / auténtica\}

a-FEM artist true authentic

'a \{true / authentic\} artist'

Moving on to ESTIs, they can also be modified by a preposed adjective of veracity, as illustrated in (21)a, or by a postposed adjective of veracity, as exemplified in (21)b. Following up on the restrictions observed by Masià (2017), gitano is a vague noun when the adjective of veracity precedes it (and hence it is associated with a set of-in this case, negative-dimensions with ideal values) and it denotes a possibly narrow set of members in the ethnic group when the adjective of veracity follows it.

$$
\begin{aligned}
& \text { a. un auténtico gitano } \\
& \text { a.MASc authentic Romani } \\
& \text { 'a \{true/ authentic\} Romani_ESTI' } \\
& \text { b. un gitano auténtico } \\
& \text { a.MASc Romani authentic } \\
& \text { 'a \{true/ authentic\} Romani' }
\end{aligned}
$$

So, unlike the artist case, in the case of ESTIs, both in the emphatic un construction and in the prenominal auténtico modification, the ESTI picks up on some kind of negative 
idealisation, referencing a set of stereotypical vices-explaining its usual pejorative nature. In postnominal auténtico modifying gitano, as in $(21) \mathrm{b}$, the term denotes membership, and it may have some positive connotations (which can be also the case of artista auténtico).

Such evaluative predicates can always be negative or positive: María es una auténtica artista (with the prenominal adjective of veracity) is usually understood as complimenting María. But one can have the idea that artists are presumptuous silly childish people, in which case María es una auténtica artista would mean that María is presumptuous and silly and childish in a high degree. Cases like Julio es un auténtico vendedor ('Julio is a true salesman', with the adjective of veracity in prenominal position) may be a better example: the same sentence from different lips may be praising or criticizing Julio. In the case of ESTIs, Manuel es un auténtico gitano ('Manuel is an authentic Romani', with prenominal auténtico) can also imply positive or negative properties; either Manuel is a \{traitor, robber ... $\}$ or Manuel is a free spirit, loyal to the community, .....$^{14}$

\subsection{Interim summary}

Nouns that behave as ESTIs have two main features: first, they are terms (either nouns or adjectives) that refer to ethnic groups or professions, and second, they carry an associated set of negative stereotypical properties. These characteristics make them suitable in two possible predicational environments in Spanish, with either a classificatory interpretation (as bare predicates), or an evaluative interpretation (introduced by the indefinite determiner). Being evaluative predicates, ESTIs share properties with a broader set of nouns, which occur in specific syntactic structures (such as the $N_{1}$ of an $N_{2}$ construction or as bare exclamatives).

\section{ESTIs as pejoratives}

\subsection{Introduction: how ESTIs insult twice}

\footnotetext{
${ }^{14}$ On this idea, see also footnote 13. Note, however, that ESTIs are unlike other evaluative predicates in that their relation with the negative stereotype is both much more stable and salient than the relation between e.g., 'artist' and its stereotype (positive or negative). On the other hand, all ethnic terms can express a positive meaning, especially within -or at least arising from- the ethnic community (the same can be said about terms of professions). What is peculiar concerning ESTIs is that their associated negative stereotype is very widespread outside the ethnic community, to the extent that the term has become a way to denote the stereotype (i.e. the cluster of properties that form such a stereotype). The praising use of gitano or any other ethnic or social terms that are recurrently used as insults in auténtico environments requires much more context, which indicates that such uses may be the effect of pragmatics. Out of the blue, auténtico gitano means robber, liar, etc. It is a default reading that can also have another, positive, reading. But audiences would not get this other reading unless the reading is put in the adequate context.
} 
Gitano is probably the best exemplar of the category of ESTIs: gitano can have an extensional and neutral use, used by Romani and non-Romani alike. But it can also have a pejorative meaning, such that if a speaker calls $A$ gitano in this second sense, she will be thereby insulting $A$, accusing $A$ of being a robber, or a liar, or dirty, or all these and more things at the same time; by using gitano as an insult, the speaker also insults the Romani people at large. The pejorative meaning of portera 'doorwoman' conveys the idea of someone who spends the day gossiping, whose own life seems to be less important to themselves than the lives of the others. The ESTI has clear sexist connotations, as it is only used in the feminine variant (doormen are not assumed to be as gossiping as much as doorwomen). ${ }^{15}$ Camionero 'truck driver', in turn, conveys the idea that the targeted person is very rude, crude, and probably sexist. Pejorative uses of viejo 'old man' and vieja 'old woman' refer to stereotypes associated to these two groups of the population: old men and women are assumed to be boring, grumpy, bitter and picky. Adolescente 'teenager' conveys the idea of someone who is volatile, nonthoughtful, and not very serious. Finally, moro 'Moor' is not such a good exemplar, but it is perhaps a more interesting case- perhaps too interesting and complicated to deal with it here. Moro can have (at least) three different uses in the Spaniards' common talk. Some people use it with a neutral, extensional, meaning: moro simply designates someone coming from North Africa. However, for many people moro is a slur and is used as such, i.e., it is a demeaning way to refer to people coming from North Africa. Additionally, it has another pejorative meaning: if someone says Mi novio es un moro ('My boyfriend is a Moor', with emphatic un), the meaning is that the boyfriend is superjealous, possessive and controlling —and, crucially, this boyfriend would not come from North Africa.

The biggest, more obvious, difference between ESTIs and slurs is that slurs are typically and originally demeaning, ${ }^{16}$ whereas terms that are ESTIs have a purely extensional neutral use. Additionally, when ESTIs are actually used as insults, they are usually directed at people not in the neutral extension (i.e., one uses a pejoratively-meant gitano to insult a non-Romani, not a person of the Romani community). Thus, we will scarcely find "weapon" uses of ESTIs (Camp, 2016), i.e., demeaning uses directed at an addressee that belongs to a particular ethnic or social group. Also, ESTIs are two times

\footnotetext{
${ }^{15}$ As for the neutral use, a doorperson in Spain is someone who manages the main entrance of an apartment building.

16 There are well-known non-pejorative uses of slurs, for instance after appropriation or linguistic reclamation (Brontsema 2004, Anderson and Lepore 2013, Ritchie 2017, Anderson 2018, a.0.). For the time being we will set such uses aside, as they are not relevant to the discussion concerning differences between ESTIs and slur-words at this point.
} 
insulting: speakers who use an ESTI insult the addressee, but they also insult a social or ethnic group. Thus, by using gitano as an ESTI, speakers insult their addressees (calling them liars, robbers, etc.), but crucially they also insult Romani people at large by conveying that Romani people are liars, robbers, etc. This second layer of insult takes the form of a generic that expresses a stereotypical negative view and is not-at issue (NAI). The Al content of slurs is often said to be an extension, a group of people (though see Hom, 2008), whereas the Al content of an ESTI is a stereotype, which can be understood as a set of weighed features that is used to categorise (akin to a prototype). ${ }^{17}$ The NAI content of a slur is plausibly attitudinal (see below), while the NAI content of an ESTI is a generic that expresses the negative stereotypical beliefs a community has about the target group. As a speaker of an ESTI endorses the social stereotype of a certain group when using the ESTI, the content that they convey is that they do believe that the group is as the stereotype depicts it.

\subsection{ESTIs: Al and NAl content (in comparison with insults and slurs)}

Our investigation of ESTIs is novel because it delineates a new category of words with pejorative meaning. We will begin by comparing the properties of ESTIs with those of slurs and insults, using diagnostics from the philosophical and semantics literature. Based on the conclusions drawn from these diagnostics, we propose to formalise ESTIs using a multi-dimensional model. There are also plausible differences between ESTIs and slurs concerning social meaning that stem from how ESTIs and slurs relate to their NAl content. We will also briefly comment on that issue in Section 3.2.

Following recent literature on meaning types (Simons et al. 2011, Tonhauser et al. 2013, Beaver et al. 2017), we assume that, despite heterogeneity, it is interesting to study the contents that are not relevant to the main topic or Question Under Discussion as being $\mathrm{NAI}$, irrespective of whether they are Conventional Implicatures (in the sense of Potts 2005) or presuppositions. Moreover, as Simons et al. (2011) have shown, we will treat projectivity (i.e., the ability to survive in the syntactic scope of operators such as negation, the antecedent of a conditional or a question) as a property NAI content can have. ${ }^{18}$

\footnotetext{
17 The word stereotype is used in several different ways in the literature. Here we will use it to refer to a categorization device that has a prototypical structure (basically: features and weighs), but that, unlike a prototype, is not an abstraction from encountered exemplars. Rather, a stereotype is typically based on social prejudices. For stereotype as sets of beliefs, we will use stereotypical beliefs.

${ }^{18}$ Although see, e.g., Martin (2016) on an account where projection and addressing the QUD are explicitly separate.
} 
Among the types of NAI content, Gutzmann (2015) classifies ethnic slurs in the class of expressively colored expressions, building on Frege's (1897/1979) notion of coloring as illustrated for cur (to be compared to dog) and on Potts's (2007) notion of expressive (as a term that identifies independent, speaker-oriented, utterance-anchored, emotionally-charged content). Unlike other expressives such as damn, expressivelycolored expressions (and by extension ethnic slurs) are said to convey both Al and NAI content. That is, according to Gutzmann, an ethnic slur denotes an ethnic group and, at the same time, conveys a derogatory attitude. In this sense, they fall within the group McCready (2010) called mixed expressives. While this view is not universally shared (see especially Hom, 2008), it is, we take it, quite robustly shared in its general lines (see, e.g. Camp, 2013, 2016, Williamson, 2009, Jeshion, 2013). In any case, we think the "mixed expressives" view is a good starting point in our discussion. ${ }^{19}$

Other than ethnic slurs, we want to compare ESTIs to evaluative nouns used as insults, such as idiota 'idiot', which fall within Potts' (2007) expressives and Gutzmann's (2015) pejorative epithets. They are said to merely convey NAI content and no Al content, on the basis of examples such as (22).

(22) That idiot Kresge dropped the bottle again. (Potts 2007b: 168)

To tease apart the $\mathrm{Al}$ and NAI content of expressive terms, we can observe the effect of an operator such as negation, (23) and (24).

(23) Wolfgang is not a Kraut.
a. Al: 'Wolfgang is not a German.'
b. NAI: 'I despise the German.'

(24) That idiot Kresge has not dropped the bottle again.
a. Al: 'Kresge has not dropped the bottle again.'
b. NAl: 'Kresge is an idiot.'

Let us now move to the Spanish data, starting with the negation of gitano 'Romani-ESTI' as our example for ESTI. As anticipated in section 2, terms that occur as ESTIs can be interpreted both as extensional terms that can appear bare as the attribute of the copula, (25), or can be evaluative terms combined with the emphatic indefinite un, (26).

(25) El Chato no es gitano.

'El Chato is not a gipsy.'
a. $\mathrm{Al}: \neg(\operatorname{romani}(\mathbf{c}))$.
b. NAI: $\varnothing$.

(26) Manuel no es un gitano.

\footnotetext{
${ }^{19}$ We will revisit theories of slurs in section 3.3.
} 
'Manuel is not a gipsy.'

a. Al: $\neg($ romani $-\mathbf{B A D}(\mathbf{m}))$

b. NAI: Romanies are robbers, liars, dirty.

A negated ethnic/social group term without un (25), only means that the subject does not belong to the extension; there is no NAI material. The pejorative use of an ethnic/social group term, i.e., an ESTI, which has un (26), has the conventional AI meaning that the target lacks the negative characteristics of that ethnic/social group, indicated in (26)a as romani-BAD. ${ }^{20}$ In addition, the ESTI conveys a NAI, negative generalisation about that group. As mentioned above, we observe that an ESTI (26) is odd if directed towards a member of the demeaned group. Let us now compare this behaviour with that of pejorative epithets (27) and ethnic slurs (28).

(27) El idiota de Iñigo no ha roto la botella.

the idiot of Iñigo NEG has broken the bottle

'That idiot Iñigo didn't break the bottle.'

a. Al: $\neg$ break(i, $\boldsymbol{\iota x}(\operatorname{bottle}(x))$.

b. NAl: $\operatorname{idiot}(\mathbf{i})$.

(28) Pascal no es (*un) gabacho.

Pascal NEG is a.MASC French_slur

'Pascal is not a French_slur.'

a. Al: $\neg($ french $(\mathbf{p}))$.

b. NAI: 'I have a negative attitude towards French people.'

As an epithet occurring in the $N_{1}$ of an $N_{2}$ construction, idiota survives the scope of negation, so the proposition that Iñigo is an idiot is conveyed as a NAI content, while the Al content is the proposition denoted by the sentence without the epithet (i.e., that Iñigo has not broken the bottle). Note that, if we place idiota as the attribute of a copular construction-which would be desirable for comparison of minimal pairs — the pejorative adjective does not convey NAI content, but is the main predicate of the Al content (as said before, it is relevant to the main topic or Question Under Discussion). This can be observed in (29).

20 The fact that in principle gitano in (26) can convey also a positive meaning (say, Manuel is not a free spirit loyal to the community) does not tell against this analysis of how ESTIs work when they are used as insults (i.e., when the meaning selected is the negative stereotype). If we are right, and the negative stereotype is one of the conventional meanings of gitano, what we are describing is how such meaning is factored out in terms of Al and NAl content. However, let us insist that such a positive meaning of un gitano is rare and requires a lot of context. As we have said before, such a use of un gitano is akin to phrases such as un Lannister, such that Manuel no es un gitano would be relevantly similar to Tyron no es un Lannister ('Tyron is not a Lannister'), meaning "Tyron does not share the values that the Lannisters are supposed to have". We even have doubts about whether the sentence by itself, without prosodic emphasis or the addition of auténtico, would success in conveying the positive meaning. Thanks to a referee for reminding us at this point that (26) could have a different reading. 
(29) Iñigo no es un idiota.

Iñigo NEG is a.MASC idiot

'Iñigo is not an idiot.'
a. Al: $\neg(\operatorname{idiot}(\mathbf{i}))$.
b. NAI: $\varnothing$.

So, pejorative adjectives used as insults are only NAI carriers when they are modifiers, not when they are predicates. Additionally, note that the pejorative can be introduced by the indefinite or appear as bare, as shown in (30).

(30) Iñigo no es idiota.

Iñigo NEG is idiotic

'Iñigo is not idiotic.'
a. Al: $\neg(\operatorname{idiotic}(\mathbf{i}))$.
b. NAI: $\varnothing$.

In the former case (29), we are dealing with the evaluative noun, which is introduced by emphatic un. In the latter case (30), idiota is an adjective, translated as 'idiotic', and it is expected to be a bare predicate in the copular construction.

As for ethnic slurs such as (28) above, let us note that typically slurs are quite unnatural when introduced by the emphatic indefinite, indicating that it is not an evaluative noun, unlike the pejorative noun idiota and ESTIs. Moreover, unlike our examples of ethnic/social terms in the bare condition, ethnic slurs do carry NAI content, which survives negation.

The main facts presented so far are summarized in Table1.

\begin{tabular}{|c|c|c|c|c|}
\hline \multirow[b]{2}{*}{$\begin{array}{l}\text { NOT } \\
S\end{array}$} & \multirow{2}{*}{\begin{tabular}{l}
\multicolumn{1}{c}{ Insults } \\
e.g., idiota \\
'idiot'
\end{tabular}} & \multirow{2}{*}{$\begin{array}{l}\text { Slurs } \\
\text { e.g., gabacho } \\
\text { 'French' }\end{array}$} & \multicolumn{2}{|c|}{$\begin{array}{l}\text { Ethnic/social group terms } \\
\text { e.g., gitano, portera } \\
\text { 'gipsy', 'doorwoman' } \\
\text { neutral } \quad \text { ESTI }\end{array}$} \\
\hline & & & $\begin{array}{l}\text { Manuel no es } \\
\text { gitano. }\end{array}$ & $\begin{array}{l}\text { Manuel no es un } \\
\text { gitano. }\end{array}$ \\
\hline Al & $\neg(\operatorname{idiot}(\mathbf{i}))$ & $\neg($ french $(\mathbf{p}))$ & $\neg(\operatorname{roma}(\mathbf{m}))$ & $\neg($ roma - BAD $(\mathbf{m}))$ \\
\hline NAI & -- & $\begin{array}{l}\text { 'I have a negative attitude } \\
\text { towards French people' }\end{array}$ & -- & $\begin{array}{l}\text { 'Gipsies are } \\
\text { robbers/liars/dirty' }\end{array}$ \\
\hline
\end{tabular}

Table 1 Cross-category comparison of Spanish pejorative terms

Going back to ESTIs, an utterance of (26) also states that Manuel is not a robber, a liar, etc., and so does not insult Manuel. Yet, it projects the NAI meaning that Romanies are robbers, liars, etc., thus indirectly insulting Romanies. Now, compared with slurs, we see 
that a slur utterance, (28), projects an attitudinal NAI content, whereas the content projected by an ESTI, (26), is a generic statement that has the effect of ascribing certain negative stereotypical beliefs to Romanies as a group. This is at least what we have assumed as a starting point in or discussion. We now turn to revisit the issue of what $\mathrm{Al}$ and NAI contents slurs plausibly have (always vis a vis ESTIs).

\subsection{More on the content of ESTIs and slurs: attitudes and stereotyping}

The view about slurs that we have taken to build the contrast between slurs and ESTIs assumes a thin attitudinal NAI content ("I despise group X"). ${ }^{21}$ However, different accounts of slurs either confer a richer NAI content to slurs or differ from the mixed expressives view at the level of Al content. Hom (2008) is the most notable exception to the predominant attitudinal view, as he argues that the Al content of a slur is of the form presented in (31), where ps stand for discriminatory treatments, ds for negative properties, and $X$ for the despised group.

(31) ought to be subject to $p 1+\ldots$ pn because of being $d 1+\ldots d n$, all because of being $\mathrm{X}$.

That is, when speakers say of someone, $A$, that he or she is an $\mathrm{S}$, they are stating that $A$ ought to be treated in a certain (harmful) way because $A$ has certain stereotypical features proper to the ethnic or social group $A$ belongs to. However, several other authors include stereotypical beliefs in either dimension of the content of slur words. Camp $(2013,2016)$, for instance, includes stereotypical beliefs in the NAI content of slurs, such that the attitude, according to her view, is directed not towards the slurred group, but towards the group-as-depicted by some negative stereotype. Tirrell (1999) holds that stereotypes are part of the inferential content of slurs, and Williamson (2009) argues that the negative stereotype is part of the NAI content (a conventional implicature) of the slur. On the other hand, it could be said that ESTIs also have an attitudinal component: one would not use the ESTI gitano if one did not have a negative attitude towards Romanies.

\footnotetext{
${ }^{21}$ Several authors (e.g. Williamson, 2009, Marques \& Garcia-Carpintero, forth.) have rightly objected to this simple expressivist view: if the NAI content of a slur is just an expression of a subjective attitude, the audience should have no problem in accepting the use of the slur. However, this is not how we, as the audience, react to the use of a slur. Marques \& GarcíaCarpintero (forth.) argue that the NAl content of slurs has a normative component: "one must derogate group F". We are not convinced that such normative content has to also include reference to stereotypical features of the target group, as Marques and García-Carpintero imply. In any case, for the purpose of this paper, it does not matter much that the thin attitudinal view is not correct. The contrast between slurs and ESTIs can be drawn also if the NAI content of slurs is normative (see below).
} 
So the question may arise whether we have exaggerated the differences between one set of terms and the other. But before we tackle this issue, let us remind the reader where we are: we have already provided several linguistic arguments in Section 2 that show how slurs and ESTIs are different kinds of terms. Namely, although both kinds of terms are pejoratives, only ESTIs behave as evaluatives. What we will do now is examine in a bit more detail their differences pertaining to content, in particular to the role that stereotyping and attitudes play in each case. In this respect, the most obvious difference between ESTIs and slurs lies in their Al content. The Al content of an ESTI is the set of properties that the social stereotype ascribes to the targeted group. In Hom's view, this set of properties form part of the Al content of a slur as well, but even in this case there are deep differences between the Al content of an ESTI and the Al content of a slur. First of all, in Hom's view John is a K has a prescriptive content that John is an ESTI by all lights lacks. Also, John is an ESTI simply states that John has a number of properties that the socially shared negative stereotype ascribes to the insulted group, whereas the role that the stereotype plays in the Al content of the slur according to Hom is motivational: it justifies the prescriptive content. That is, it putatively provides the reason why we should treat members of the group in a bad way. So slurs on his account include an evaluative component, but, linguistically, they are not themselves evaluatives, as ESTIs are (see above).

This said, we think that there are sharper differences between the role that attitudes (or prescriptions about attitudes) and stereotypes play in ESTIs and the role they play in slurs, which incidentally make us think that the simple attitudinal/prescriptional view on slurs is overall preferable to other accounts. Although our purpose is not to commit to any particular view on slurs, we concur with Jeshion's (2013) idea that stereotypes and stereotypical beliefs are associations elicited by the use of slurs rather than part of their (Al or NAl) content. Our view is that stereotyping is not essential to slurring, but is essential to using ESTIs, while expressing or prescribing a negative attitude is essential to slurring but not to using ESTIs. To begin with, some slurs may actually lack a stereotypical component. Our own example gabacho is a case in point. Spaniards' current use of gabacho may not involve any stereotype of French people; rather, we would say that it is used just to look down on French people. Speakers are aware that it is a word that they can use instead of francés 'French', which has the effect of denigrating French people, but it is at least debatable whether many of them would also believe that gabacho elicits particular stereotypical beliefs that francés does not. We wanted to point towards this possibility, because the literature often focuses on slurs that have strong 
stereotypical associations and generalizes from there. However, a second reason why we think that stereotypes play different roles in slurs vis a vis ESTIs is that speakers could always detach themselves from the ascription of stereotypical properties, (32), while the stereotypical component of an ESTI is compulsory, since it appears already in the Al content, (33).

(32) I know you are not [stereotype], but you'll still always be a Kraut.

(33)\#Sé que no eres un-a chismos-a, pero siempre serás un-a porter-a. ESTI know.1SG that NEG are.2SG a-FEM gossip-FEM but always are.FUT.2SG a-FEM doorperson-FEM '\#l know you are not a gossip, but you'll still always be a doorwoman.'

In the case of the role of attitudes, things seem to be the other way around. For instance, it will typically be the case that the speaker of the ESTI in (26) has a negative attitude towards Romanies, but such an attitude is not part of an ESTI's NAI content: a speaker can actually cancel the expression of the attitude, but not that of the generic statement. An influential person in the criminal underworld who values some of the stereotypes associated with gitano could say (34).

(34) Por desgracia, Manuel no es un gitano.

by misfortune Manuel NEG is a.MASC Romani.MASC

'Unfortunately, Manuel is not a Romani-ESTI.'

In this case, the speaker, while committing to the generic NAI content, and thus potentially offending Romani people, does not express a negative attitude towards them. She would endorse the negative stereotype, but the attitude she expresses would be positive rather than negative. A way to see the difference between attitudes in slurs vs. ESTIs is this: if the speaker is not totally ignorant of what a certain slur, say, Kraut, means, it seems a performative contradiction (appropriation uses aside) to say the slurcontaining (35). In contrast, it does not seem like a performative contradiction to utter the ESTI-containing (36).

(35)\#You are a Kraut. I like people like you.

(36) Eres un gitano. Me gusta la gente como tú. are.2sG a.MASc Romani me like the.FEM people like you

'You are a Romani-ESTI. I like people like you.'

Let us be clear on one issue: ESTIs like gitano are used typically as insults. In such typical cases, the speaker conveys a negative attitude towards Romanies. It is certainly strange to have a positive attitude towards a series of vices (which is what romani-BAD) 
stands for. The point we are trying to make is that, strange as it is, it is in some contexts possible to not have such a negative attitude towards such vices and thus to not convey a negative attitude towards Romanies when using gitano in its pejorative sense.

We take it that, ideally, one could distinguish two ways of being racist/classist: one is by simply despising people of a different ethnic or class origin; the other one is by negatively stereotyping a different ethnic or class group. Usually, a racist/classist does both things at the same time, but ideally again, it is possible to separate both components. ESTIs seem to display more the stereotype-based racism/classism, while slurs seem to be more on the despising-type racism/classism side.

Nunberg (2017) argues that also the attitudinal component of a slur is defeasible. He uses the non-appropriation example of redskin, which for some people has positive connotations, e.g., of bravery and authenticity. People who use redskin with those associations in mind have a positive attitude towards Native Americans, so it cannot be said that the NAI content of redskin is one of contempt (or, in general, negative). Yet, according to Nunberg, redskin in the mouths of these well-meaning people is still a slur, as it potentially offends Native Americans, who would refuse any characterisation that comes from the one-sided view that hegemonic narratives have construed about them. Nunberg's own view about the NAI content of slurs is that it derives from a Manner Implicature: the slurring speaker chooses to speak in the way that prejudiced and racist people speak. If Nunberg is right about this, then the difference between slurs and ESTIs should be located at a different level: while slurs' demeaning content arises by way of a conversational implicature, ESTI's demeaning content is part of its semantics. It is possible to find well-meaning uses of gitano but those will not be pejorative. ${ }^{22}$ However, when gitano is used to refer to the stereotype "liar, robber, etc.", its pejorative, stereotypical, content is inevitable. Using the term gitano to tell someone that he/she is a liar and a robber cannot but demean the people of the Romani community. The NAI content, confirming the negative stereotypical beliefs towards that ethnic group, follows automatically.

\subsection{Social meaning}

Related to this: there are also some differences between ESTIs and slurs at the level of social meaning, which also reveals something about their Al and NAI content. ESTIs, as

\footnotetext{
${ }^{22}$ On this, see subsections 2.2. and 2.4., and especially footnote 13.
} 
well as slurs, are carriers of social meaning (Eckert, 2008); that is, they embed a fluid cluster of social information that tells something about the values and beliefs of the speaker uttering the slur/ESTI. Typically, the use of slurs and ESTIs conveys information concerning the speaker's values as well as about certain assumptions she makes about the audience. Speakers who use ESTIs and slurs always signal themselves as prejudiced against certain ethnic/social groups, disregarding their intentions. That is, even when the speaker has not willingly chosen to use a slur or an ESTI, she emerges as a racist/classist and prejudiced person. Yet, slurs can have developments in this dimension that ESTIs cannot.

A speaker who states that a certain person, Manolo, is a gitano-ESTI expresses that it is correct to apply the stereotype of Romanies to Manolo and conveys that the people of the Romani community are liars, cheaters and thieves (or that Romanies are like the stereotype depicts them). By doing this, this speaker signals herself as prejudiced and racist. This is a direct consequence of the NAI content attached to any utterance of (26). In many cases discussed in the literature, social meaning is attached to variants or alternatives (Eckert, 2008, Burnett, 2016: e.g., using -ing or -in', Burnett, forthcoming), such that each variant (e.g. - -ing) correlates with a certain kind of social group and signals that the user of the variant belongs to that group. This is also how Nunberg (2017) deals with the issue of the social meaning of slurs: according to him, slurs have the social meaning they have because they are the way that certain (racist, classist, prejudiced) groups refer to other groups. There are usually several different variants or alternatives to refer to a certain group of people: using one instead of another signals affiliation with a way of thinking. To the extent that social meaning in these cases requires variants or alternatives, if we were to remove one of the alternatives and homogenise ways of speaking, the social meaning attached to the other, preserved, alternative would disappear. For example, suppose that little by little the -ing variant disappears and everybody pronounces -in'. In such a case, an external observer would not attach any social significance to the use of $-i n$ '.

Now we are not sure whether the same applies to slurs (i.e., we are not sure whether the social meaning attached to slurs is related to the existence of a neutral alternative). Most authors take it that slurs contrast with "neutral" counterparts and relate their social significance to the existence of such counterparts (e.g., Bolinger, 2017, Nunberg, 2017). However, that the Romans had only the word 'barbarian' to refer to the people not belonging to the Roman or the Greek civilisations does not seem to make 'barbarian' less pejorative and racist. On the other hand, a slur can become dominant (vis a vis its 
alternatives) precisely because it loses its derogatory connotations, via reappropriation and afterwards normalisation. In such a case, the slur effectively ceases to signal racism/classism/sexism. However, this is something that would not happen with an ESTI, because no matter what, we would think that the insulting use of gitano is racist and prejudiced, even if it were the only word that Spanish speakers had to refer to people who are conceived as liars, cheaters, thieves, etc. So, it seems that the social meaning associated with an ESTI is associated with its contribution to NAI content (i.e., the negative stereotyping of the target group), which is stable in a way that the NAI (mainly attitudinal) content of a slur is not. That is, insofar as an ESTI has the Al content that it has, it cannot but convey the NAI content that it conveys. The case of the slur is different: it can retain its $\mathrm{Al}$ content, but change its $\mathrm{NAI}$ content. ${ }^{23}$

\subsection{Summary}

In Section 2 we showed that ESTIs and slurs appear in different linguistic environments. This is enough to believe that they are different kinds of pejoratives. In this section we have focused on their differences at the level of Al and NAI content. The comparison is not straightforward, as there are various accounts of the contents of slurs. We have tried to show that differences will arise no matter what theory of slurs one endorses. Still, we have tried to provide arguments for the view that stereotyping is essential to ESTI-ing while attitude expression (modulo evolutions such as appropriation) is essential to slurring. Finally, by exploring the issue of social meaning, we have suggested that phenomena such as appropriation can be described as having effects only on the NAI content of slurs. In the case of ESTIs, ESTIs can only stop being pejorative if they change their Al content.

\section{Conclusions}

Ethnic and social terms that are used as insults while retaining a neutral, non-slurring, meaning, form a class of pejorative expressions that has not been studied in the by now rich literature on pejoratives. One plausible reason for this gap is that examples do not abound in English. In this paper we have focused on European Spanish, where this kind of terms is widespread. We have shown that ESTIs form a class within pejoratives using several linguistic tests that reveal that ESTIs, unlike slurs, appear in the syntactic environments of evaluatives. We have analysed the contribution that ESTIs make to contents as occurring in two dimensions: at the at-issue level, the meaning of an ESTI is a stereotype; at the not-at-issue level, it is a generic that captures the socially shared

\footnotetext{
${ }^{23}$ In an account such as Hom's (2008), this point would have to be expressed differently. But the difference would persist under a different description of the phenomenon.
} 
stereotypic beliefs in a community. We have compared ESTIs with slurs also with respect to their content, and in particular with respect to the roles that stereotyping and attitude expression play in the articulation of such contents. Our conclusion is that while slurs' pejorative content is basically attitudinal or prescriptive, ESTIs denigrate by negative stereotyping.

\section{Acknowledgments}

Thanks for comments and suggestions to Manuel García-Carpintero, Violeta Demonte, Andrea Beltrama, Heather Burnett, audiences at the Sociolinguistic, Psycholinguistic and Formal Perspectives on Meaning Workshop and the $19^{\text {th }}$ Szklarska Poreba Workshop, as well as to two anonymous referees of this journal. We are of course responsible for any remaining errors. Special thanks are due to Dan Zeman, who brought the "tigan" issue to us. This research has been partially supported by projects VASTRUD (PGC2018-096870-B-I00) and PROLE (PGC2018-093464-B-I00), and predoctoral grant BES-2016-076783, funded by the Ministry of Science, Innovation and Universities (MiCIU) / Spanish Research Agency (AEI) and the European Regional Development Fund (FEDER, UE), by the IT1396-19 Research Group (Basque Government), and GIU18/221 (University of the Basque Country, UPV/EHU).

\section{References}

Anderson, L. 2018. Calling, addressing, and appropriation. In Sosa, D. (ed.), Bad Words, Oxford: Oxford University Press.

Anderson, L. \& E. Lepore. 2013. Slurring words. Nous, 47(1), 25-48.

Barsalou, L. W. 1985. Ideals, central tendency, and frequency of instantiation as determinants of graded structure in categories. Journal of Experimental Psychology: Learning, Memory, and Cognition, 11, 629--649.

Beaver, D., M. Simons, C. Roberts, \& J. Tonhauser 2017. Questions Under Discussion: Where information structure meets projective content. Annual Review of Linguistics, 3, 265-284.

Bolinger, D. 1972. Degree Words. The Hague: Mouton.

Bolinger, R. J. 2017. The Pragmatics of Slurs. Noûs 51 (3), 439-462.

Bosque, I. 1993. Sobre las diferencias entre los adjetivos relacionales y los calificativos, Revista Argentina de Lingüística, 9, 9-48.

Bosque, I. 1996. Por qué determinados sustantivos no son sustantivos determinados. Repaso y balance. In Bosque, I. (ed.), El sustantivo sin determinación. La ausencia de determinante en la lengua española, Madrid: Visor Libros, 13-119. 
Bosque, I. 1999. El nombre común. In Bosque, I. and V. Demonte (eds.), Gramática descriptiva de la lengua española, Volume I, Madrid: Espasa Calpe, 3-76.

Brontsema, R. 2004. A queer revolution: Reconceptualizing the debate over linguistic reclamation. Colorado Research in Linguistics 17(1), 1-17.

Burnett, H. 2019. Signalling Games, Sociolinguistic Variation and the Construction of Style. Forthcoming in Linguistics \& Philosophy.

Camp, E. 2013. Slurring Perspectives. Analytic Philosophy, 54, 330-349.

Camp, E. 2016. A Dual Act Analysis of Slurs, In Sosa, D. (ed.), Bad Words, Oxford: Oxford University Press.

del Pinal, G. \& Reuter, K. 2016. Dual Character Concepts in Social Cognition: Commitments and the Normative Dimension of Conceptual Representation. Cognitive Science, 1-25.

Doetjes, J., \& J. Rooryck. 2003. Generalizing over Qualitative and Quantitative Constructions. In Coene, M. and Y. D'hulst (eds.), From NP to DP, Amsterdam: John Benjamins, 277-96.

Eckert, P. 2008. Variation and the indexical field. Journal of sociolinguistics, 12(4), 453-476 .

Espinal, M. Teresa. 2013. Bare Nominals, Bare Predicates. Properties and Related Types. In Kabatek, J. and A. Wall (eds.), New Perspectives on Bare Noun Phrases in Romance and Beyond, Amsterdam: John Benjamins, 63-94.

Fernández Lagunilla, M. 1983. El comportamiento de un con sustantivos y adjetivos en función de predicado nominal: sobre el llamado un enfático. In Serta Philologica: F. Lázaro Carreter: Natalem Diem Sexagesimum Celebranti Dicata. Madrid: Cátedra, 195-208.

Fernández Leborans, M. J. 1999. La predicación: las oraciones copulativas. In Bosque, I. \& V. Demonte (eds.), Gramática descriptiva de la lengua española, Madrid: Espasa Calpe, 2357-2460.

Frege, Gottlob. 1897/1979. Logic. In Hermes, H., F. Kambartel, \& F. Kaulbach (eds.), Posthumous Writings, Oxford: Blackwell, 126-51.

Geist, L. 2019. Predication over aspects of human individuals. Linguistics 57:6, 1305-1336.

Gutiérrez-Rexach, J. 2010. Varieties of Indefinites in Spanish. Language and Linguistics Compass 4(8), 680-693.

Gutzmann, D. 2015. Use-conditional meaning: Studies in multidimensional semantics. Oxford: Oxford University Press. 
Gutzmann, D. \& E. McCready. 2016. Quantification with Pejoratives. In Finkbeiner, R., J. Meibauer \& H. Wiese (eds.), Pejoration, Amsterdam, Philadelphia: John Benjamins, 75-101.

Hernanz, M. Lluïsa. 2001. ¡En bonito lío me he metido! Notas sobre la afectividad en español. Moenia. Revista Lucense de Lingüística y Literatura 7, 93-109.

Heycock, C. 1994. Layers of Predication. The Non-Lexical Syntax of Clauses. New York: Garland.

Higgins. 1979. The Pseudo-cleft Construction in English. New York: Garland.

Hom, C. 2008. The Semantics of Racial Epithets, Journal of Philosophy, 105, 416--440 Jeshion, R. 2013. Slurs and Stereotypes. Analytic Philosophy 54, 314--329.

Jeunot, D. 1983. 'Il est médecin' (pourquoi pas?). In Fisher, S. \& J.J. Franckel (eds.), Linguistique, énonciation. Aspects et détermination, Paris: École des Hautes Études en Sciences Sociales, 81-95.

Korzen, I. 1982. Perché 'Mario é medico' ma non ‘`Mario é mascalzone?', Studi di grammatica italiana 11, 137-178.

Knobe, J., Prasada, S., \& Newman, G. 2013. Dual character concepts and the normative dimension of conceptual representation. Cognition 127, 242-257.

Marques, T \& García-Carpintero, M. Forth. Really expressive presuppositions and how to block them. Grazer Philosophische Studien

Martin, S. 2016. Supplement Update. Semantics \& Pragmatics 9, 1--61.

Masià, M. 2019. A typology of evaluative nouns. In Feldhausen, I., M. Elsig, I. Kuchenbrandt \& M. Neuhaus (eds.) Romance Languages and Linguistic Theory 2016. Selected papers from 'Going Romance' Frankfurt 2016. 296-312. Amsterdam: John Benjamins.

Masià, M. 2018. Extreme nouns and maximizers. In Sauerland, I. \& S. Solt (eds.), Proceedings of Sinn und Bedeutung 22, Vol. 2, ZASPiL 61, Berlin: ZAS, 143161.

Masià, M. 2017. Adverbial adjectives and nominal scalarity. PhD Thesis. Universitat Autònoma de Barcelona.

Matushansky, Ora. 2002. A Beauty of a Construction. In Mikkelsen, L. \& C. Potts (eds.), Proceedings of the 21st West Coast Conference on Formal Linguistics, Somerville, MA: Cascadilla Press, 264-77.

McCready, E. 2010. Varieties of conventional implicature. Semantics \& Pragmatics 3 (8), 1-57.

Mlkkelson, L. 2005. Copular Clauses. Specification, Predication and Equation. Amsterdam: Benjamins. 
Milner, J. 1978. De la syntaxe a l'interprétation : quantités, insultes, exclamations. Paris: Éditions du Seuil.

Moro, A. 1997. The Raising of Predicates. Predicative Noun Phrases and the Theory of Clause Structure. Cambridge: Cambridge University Press.

Morzycki, M. 2009. Degree Modification of Gradable Nouns: Size Adjectives and Adnominal Degree Morphemes. Natural Language Semantics 17 (2): 175-203.

Munaro, N. 2006. Verbless Exclamatives across Romance: Standard Expectations and Tentative Evaluations. University of Venice Working Papers in Linguistics 16: 185-209.

Nouwen, R. 2011. Degree Modifiers and Monotonicity. In Égré, P. \& N. Klinedinst (eds.), Vagueness and Language Use, Basingstoke: Palgrave Macmillan, 146-64.

Nunberg, G. 2017. The social life of slurs. In Fogel, D., D. Harris \& M. Moss (eds.), New Work on Speech Acts, Oxford: Oxford University Press, 237-295.

Partee, B. 1986. Ambiguous pseudoclefts with unambiguous be. In Berman, S, J. Choe \& J. McDonough (eds.), Proceedings of the North Eastern Linguistic Society 16, Amherst, MA: GLSA, 354-366.

Pollock, J.Y. 1983. Sur quelques propriétés des phrases copulatives en français, Langue française 58, 89-125.

Portolés, J. 1993. Atributos con un enfático. Revue Romane, 28(2), 218-236.

Portolés, J. 1994. La metáfora y la lingüística: los atributos metafóricos con un enfático. In Demonte, V. (ed.), Gramática del español, México: Colegio de México, 531556.

Potts, C. 2005. The Logic of Conventional Implicatures. Oxford: Oxford University Press.

Potts, C. 2007. The Expressive Dimension. Theoretical Linguistics 33 (2): 165- 97.

Reuter, K. 2019. Dual-Character Concepts. Philosophy Compass, 14 (1).

Rigau, G. 1999. La estructura del sintagma nominal: Los modificadores del nombre. In Bosque, I. \& V. Demonte (eds.), Gramática descriptiva de la lengua española, Madrid: Espasa Calpe, 311-362.

Ritchie, K. 2017. Social identity, indexicality, and the appropriation of slurs. Croatian Journal of Philosophy, 17(2),155-180.

Ruwet, N. 1982. Grammaire des insultes et autres études. Paris: Éditions du Seuil

Schumacher, P.B. (2013). When Combinatorial Processing Results in Reconceptualization: Towards a New Approach of Compositionality. Frontiers in Psychology, 4: 677.

Simons, M., Tonhauser, J., Beaver, D., \& Roberts, C. 2010. What projects and why. In Proceedings of Semantics and linguistic theory (SALT 20), 309-327. 
Tonhauser, J., D. Beaver, C. Roberts, and M. Simons. 2013. Toward a taxonomy of projective content. Language 89(1): 66-109.

Suñer Gratacós, A. 1990. La predicación secundaria en español. PhD Thesis, Universitat Autònoma de Barcelona.

Suñer Gratacós, A. 1999. La aposición y otras relaciones de predicación en el sintagma nominal. In Bosque, I. \& V. Demonte (eds.), Gramática descriptiva de la lengua española, Madrid: Espasa Calpe, 523-564.

Tirrell, L. 1999. Derogatory Terms: Racism, Sexism, and the Inferential Role Theory of Meaning. In Hendricks, C. \& K. Oliver (eds.), Language and Liberation: Feminism, Philosophy, and Language, Albany NY: SUNY Press, 41-80.

di Tullio, A., \& A. Suñer Gratacós. 2008. La evolución de un como artículo enfático ante nombres de cualidad en función de atributo. In Company, C. \& J. G. Moreno de Alba (eds.), Actas del VII Congreso Internacional de Historia de la Lengua Española, 499-510.

Vicente, A. 2018. Polysemy and word meaning: an account of lexical meaning for different kinds of content words. Philosophical Studies, 175, 947-968.

Villaba, X. \& A. Bartra-Kaufmann. 2010. Predicate Focus Fronting in the Spanish Determiner Phrase. Lingua 120 (4), 819-49.

Vinet 1991. French Non-Verbal Exclamative Constructions. Probus 3 (1), 77-100.

de Vries, H. 2010. Evaluative Degree Modification of Adjectives and Nouns. MA Thesis, Universiteit Utrecht

Williams, B. 1985. Ethics and the Limits of Philosophy. Cambridge, Mass.: Harvard University Press.

Williamson, T. 2009. Reference, Inference and the Semantics of Pejoratives. In Almog, J. \& P. Leonardi (eds.), The Philosophy of David Kaplan, Oxford: Oxford University Press, 137-158. 